\title{
Comparison of geographic distribution models of white-tailed deer Odocoileus virginianus (Zimmermann, 1780) subspecies in Mexico: biological and management implications
}

\author{
Salvador Mandujano ${ }^{1 *}$, Christian A. Delfín-Alfonso ${ }^{2,3}$ \\ and Sonia Gallina ${ }^{1}$
}

\section{Abstract}

The white-tailed deer (Odocoileus virginianus) is the most widely distributed and studied ungulate in the American continent. This species is found throughout Mexico, except on the peninsula of Baja California and some areas of northern Chihuahua and Sonora. In this study we compared three geographic distribution models (Kellogg 1956; Hall 1981; Villarreal 1999) of white-tailed deer subspecies on a national scale, by state and by principal vegetation types. We found that neither the number of subspecies (13 or 14 of the 38 recognised subspecies), nor the geographical limits between subspecies coincided completely between models. Furthermore, for several subspecies, marked differences in distribution area were found depending on the distribution model used. Using multivariate analyses, we found that the 14 subspecies can be separated into three groups associated with different vegetation types: the northern subspecies associated with shrub land, the Pacific subspecies associated with temperate forest and tropical dry forest, and the south-eastern subspecies associated with tropical evergreen forest, cloud forest and tropical semi-deciduous forest. We suggest the classification of the 14 subspecies into three ecoregions. The data analyzed here is relevant to the management and conservation of the white-tailed deer subspecies and/or geographical variations in Mexico; it is also important to avoid the translocation of individuals into inappropriate areas with respect to their evolution and adaptation to different ecoregions.

Key words: distribution, ecoregions, management, Mexico, subspecies, vegetation types.

\footnotetext{
${ }^{1}$ Red de Biología y Conservación de Vertebrados, Instituto de Ecología A. C., Carretera Antigua Coatepec No. 351, El Haya, Xalapa 91070, Ver., México. E-mail: salvador.mandujano@inecol.edu.mx, autor corresponsal

${ }^{2}$ Red de Medio Ambiente y Sustentabilidad, Instituto de Ecología A. C., Carretera Antigua

Coatepec No. 351, El Haya, Xalapa 91070, Ver., México.

${ }^{3}$ Facultad de Ciencias Naturales, Universidad Autónoma de Querétaro, Av. de la Ciencia S/N Juriquilla, Delegación Santa Rosa Jáuregui, Santiago de Querétaro, C. P. 76230, Querétaro, México.
} 
El venado cola blanca (Odocoileus virginianus) es el unguiado con mayor área de distribución en el continente Americano. En México, se le encuentra en todo el territorio excepto la península de Baja California, algunas áreas del norte de Chihuahua y norte de Sonora. En este trabajo comparamos algunos modelos (Kellogg 1956; Hall 1981; Villarreal 1999) de distribución geográfica de las subespecies de venado cola blanca, a nivel del país, por entidad federativa y por tipos principales de vegetación. Se encontró que no coinciden totalmente ni en el número de subespecies (13 ó 14 de las 38 subespecies reconocidas), ni en los límites geográficos entre subespecies; además de que para algunas subespecies existen claras diferencias en las áreas de distribución dependiendo del modelo de distribución. Con base en análisis multivariados encontramos que las 14 subespecies pueden separarse en tres grupos asociados a diferentes tipos de vegetación: las subespecies norteñas asociadas al matorral xerófilo, las subespecies del Pacífico asociadas al bosque templado y bosques tropical seco, y las subespecies del sureste asociadas al bosque tropical perennifolio, bosque mesófilo y bosque tropical subcaducifolio. Sugerimos clasificar a las subespecies en tres ecoregiones. La información generada es relevante para el manejo y conservación de las subespecies y/o variaciones geográficas del venado cola blanca en el país, y evitar translocar individuos a sitios que no les corresponden de acuerdo a su evolución y adaptación a las diferentes ecoregiones.

Palabras clave: distribución, ecoregiones, manejo, México, subespecies, tipos de vegetación.

The white-tailed deer Odocoileus virginianus (Zimmermann 1780) is the most widely Introduction distributed and studied cervid in the American continent (Gallina et al. 2010). It is found from a latitude of $60^{\circ} \mathrm{N}$ in the south of Canada, through most of the United States, except some regions of the southeast, throughout Central America, and into South America in the north of Brazil and south of Peru at a latitude of $15^{\circ}$ S (Smith 1991; Gallina et al. 2010). In Mexico this species is found throughout the country, except on the peninsula of Baja California and in some areas of northern Chihuahua and Sonora (Leopold 1959). The high levels of reproductive, behavioural and ecological plasticity observed in this species, are factors that have allowed it to expand its geographic distribution (Baker 1984). As a consequence, this browser cervid inhabits an extensive variety of different plant communities. In Mexico this species is found in temperate pine, oak and fir forests, mixed oak - pine forest, shrub land, tropical dry forest, semi-evergreen and evergreen forests, subaquatic vegetation and secondary vegetation (Galindo-Leal and Weber 2005).

Thirty eight subspecies of the white-tailed deer have been described, 14 of which are found in Mexico (Smith 1991). Although the level of subspecies is frequently employed for conservation and management purposes, from a biological point of view its definition is controversial. Theoretically, subspecies are groups of local populations, within a species, that share a geographical range and common characteristics (genetic and phenotypic), that are adapted to the environmental conditions found in their habitat, and that are separated from other populations by some kind of geographical or climatic 
barrier; such qualities allow for the distinction of one subspecies from another (Frankham et al. 2002). However, the classification of the currently recognised white-tailed deer subspecies is entirely based on morphological characteristics (e.g., size, pelage colour, size and shape of male antlers), from just a few museum specimens (Kellogg 1956), and only a limited studies exist that present detailed or quantitative morphological or genetic data (e. g., Krausman et al. 1978; Sheffield et al. 1985; Cronin 1991a, 1991b; Mathews and Porter 1993; Ellsworth et al. 1994; Anderson et al. 2002; Van Den Bussche et al. 2002; DeYoung et al. 2002, 2003). For Mexico, very little information about morphometric or genetic variability in white-tailed deer is available. Studies exist for four north-eastern subspecies (Logan-Lopez et al. 2006, 2007), five subspecies in the country (Calderón-Lobato 2009), and three subspecies in the state of Michoacan (Chassin, personal communication). For these reasons, there is a clear need for further research in this topic.

The range of individual variation found in white-tailed deer, especially in size, antler details, and pelage colour, is remarkable and has been used for their subdivision into subspecies (Kellogg 1956). However, one form can pass gradually into another, especially where there are no abrupt changes in physiography. Specimens from certain regions might, with equal propriety, be referred to as either of the contiguous subspecies. But where abrupt changes in physiography do occur, such as the change from plains to high mountains, the deer tend to respond along rather sharp lines of differentiation. Generally, among the subspecies of white-tailed deer, the larger forms are found in the north and the smaller forms in the south. For example, the maximum size is reached in those races extending westward from the Atlantic coast across southern Canada and northern United States. The minimum size is found in O. v. rothschildi, inhabiting Coiba Island off the Pacific coast of Panama. In Mexico, the largest subspecies is O. $v$. texanus, while the smallest is O. v. acapulcensis. Variation in antler-formation seems to correlate mainly with various physical factors, among which are size, maturity, and general physical condition (Villarreal 1999). The larger northern subspecies carry larger antlers, with more numerous tines, than do the smaller southern forms. For example, in O. v. acapulcensis the antlers, even in fully mature bucks, may be reduced to single spikes; in contrast, in O. v. texanus subsidiary tines are more prevalent. Individual and subspecific variations in colour are so great that they are perplexing to explain, and gradations are so numerous that they are difficult to distinguish. The pelages usually are quiet different among seasons. For example, in the northern subspecies the winter and summer colour differ, while in Mexico there are variations between wet and dry seasons. In general, summer or wet season colour being predominantly brownish or greyish, while winter or dry season is tawny. The most vivid coloration, ranging from tawny to rich orange-cinnamon, is shown by some of the subspecies inhabiting the tropical lowlands in Mexico and Central America. The colours of individuals from the high mountains of these regions usually are dull and dark. A further factor confusing the situation is the widespread translocation of various subspecies of white-tails into geographic ranges properly belonging to others.

The white-tailed deer is a highly valued species in Mexico for many reasons, including: protein consumption, commerce, the elaboration of artisan crafts, and as an important component in the rituals of indigenous cultures (Mandujano and Rico-Gray 
1991; Greenberg 1992; Gonzalez-Perez and Briones 2000; Naranjo et al. 2004). Today the hunting of this species continues to be important, both for subsistence and trophy hunting. The white-tailed deer is the most important game species in Mexico and its cynegetic exploitation has increased notably in Wildlife Conservation, Management and Sustainable Utilization Units (in Spanish: Unidades de Manejo y Aprovechamiento para la Conservación de la Vida Silvestre, or UMAs, Montiel et al. 1999; GonzalezMarin et al. 2003; Segovia and Hernandez 2003; Villarreal-Espino 2006), providing an important source of income, particularly in the north of the country (Villarreal 1999). In consequence, UMA management has led to a greater national demand for the hunting of white-tailed deer and an urgent need for reliable biological and ecological data in order to sustainably manage the different populations and subspecies. In this sense, Natural Protected Areas (in Spanish ANPs) have proven to be important areas for such studies (Gallina et al. 2007).

From a cynegetic management point of view, in Mexico only five of the 14 whitetailed deer subspecies enter into the current international trophy record books, such as those organised by the Boone and Crockett Club and Safari Club International. For this reason, these are the subspecies that are given the most attention and protection by ranchers and land owners. These subspecies are: O. v. texanus, O. v. couesi, O. v. carminis, O. v. miquihuanensis and, in recent years, O. v. mexicanus (Villarreal-Espino 2002). The remaining subspecies have not been considered as recognised trophies by national or overseas sport hunters, owing both to their smaller sized antlers and their lack of an individual category in the trophy record books. Notwithstanding, the situation is beginning to change and a greater regional importance is being placed on the hunting of each individual subspecies (Villarreal 2009). As a result, one worrying aspect of white-tailed deer management is the translocation of subspecies to different parts of the country other than those areas where they are historically found. Given this problem, the Wildlife Department of SEMARNAT (the Mexican office for the Environment and Natural Resources) requires that any animals that are translocated are of the same subspecies as those found in the local area. This legislation forms part of Article 81 of the General Wildlife Law of Mexico (Diario Oficial de la Federación 2006). This is particularly important in large UMAs, where animals are often released with little control. For this reason there is an urgent need for a database of geographic information that allows both the authorities and farm owners to gain a better understanding of the subspecies they manage, and to maintain the genetic variability of the species and, in turn, its conservation prospects. See Appendix 1 to detail description of each subspecies in Mexico.

Based on information from the Smithsonian Institution, Kellogg (1956) published an interesting map, now little known, in Taylor's (1956) book, which has been considered a classic for decades. Interestingly, the author only recognised 13 white-tailed deer subspecies in Mexico and presented geographical limits between subspecies which were discontinuous. That is, he left empty spaces in which it is difficult to define which subspecies are distributed (Fig. 1a). The distribution map by Hall (1981) presents the continuous distribution of 14 subspecies, based on records from limits of the distribution of each subspecies (Fig. 1b). This map appears to be the basis of others, such as that published by Baker (1984) which, in turn, served as the basis of the map presented 


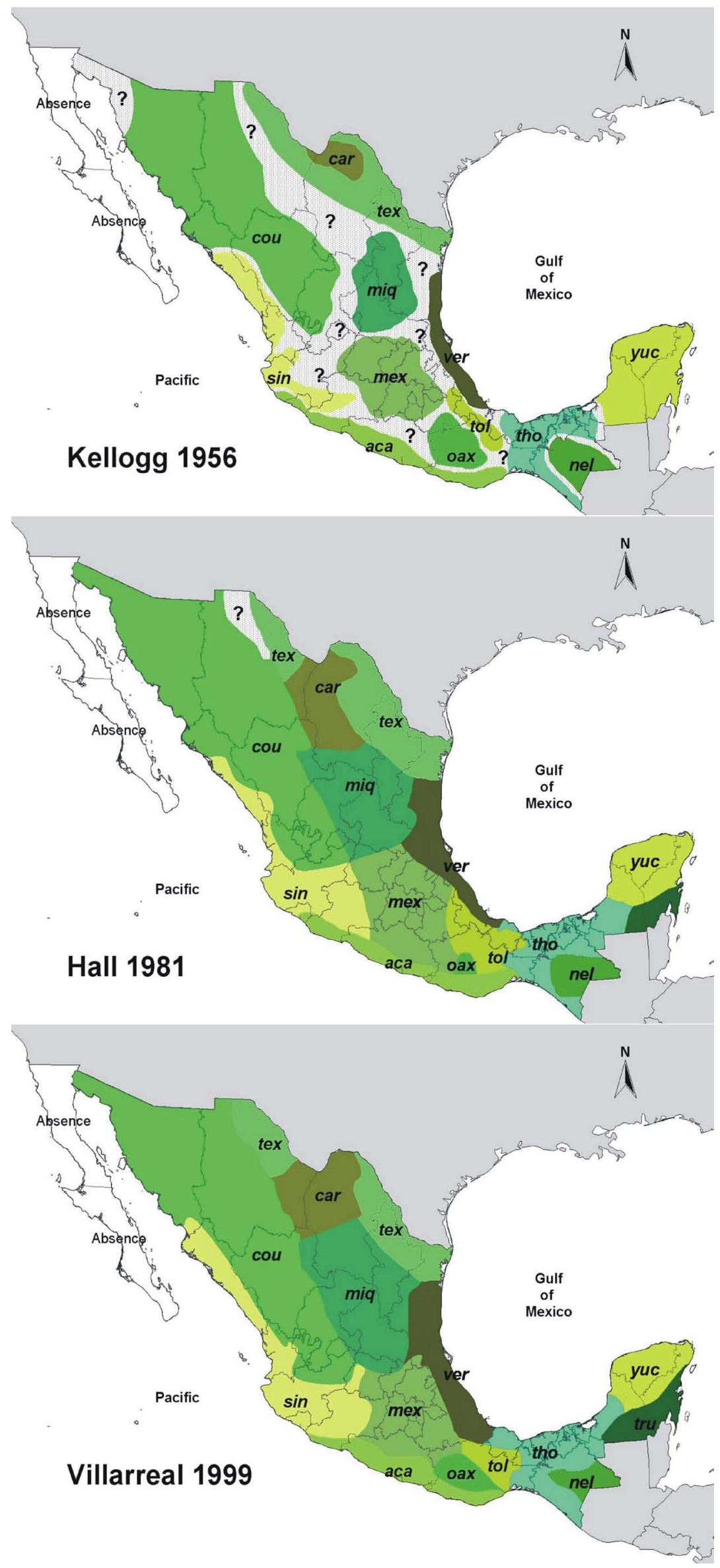

Figure 1. Distribution models of the whitetailed deer subspecies in Mexico, proposed by Kellogg (1956), Hall (1981) and Villarreal (1999). ? Indicates the regions with doubt as to which subspecies are present. In the three models, each subspecies is presented by the same colour. 
by Smith (1991) in a monograph of the species, a mandatory reference. For Mexico, Villarreal (1999) published a distribution map of the subspecies which contains some important differences with respect to the other maps previously mentioned (Fig. 1c). This book is frequently consulted by deer managers in Mexico, and the author based the map on that proposed by Baker (1984), but introduced significant changes based on field experience with the species. How comparable are these distribution models? Could differences be expected in the number of subspecies and distribution surface in each federal entity depending of the distribution model used? Considering not the taxonomic characteristics, could the 14 subspecies be classified different according with the ecological conditions where they inhabit? Which are the conservation and management implications of this distribution models comparison? The objective of this study was to compare the biogeographic distribution maps for the subspecies of whitetailed deer in Mexico (Kellogg 1956; Hall 1981; Villarreal 1999), in order to: 1) Estimate the distribution areas of the subspecies on a national scale, by state and by vegetation type. 2) Identify related groups of subspecies in function with the principal vegetation types found in the country in order to define possible ecoregions, and 3) Analyse the implications of our results for the biology and management of the 14 subspecies found in Mexico. Since a model is a graphical, mathematical, physical, or verbal representation or simplified version of a concept, phenomenon, relationship, structure, system, or any aspect of the real world, and a species distribution map is a visual representation in which a biological taxon is spatially arranged in an area, in this paper we used distribution model as a synonym for distribution map.

Sources of information used.- Information relating to the distribution of the subspecies Methods of white-tailed deer in Mexico was gathered by consulting the maps of Kellogg (1956), Hall (1981), and Villarreal (1999). Information additional was consulted in Goldman and Kellogg (1940), Miller and Kellogg (1955), Hall and Kelson (1959), Taylor (1956), Rue (1979), Hall (1981), Smith (1991), Villarreal (1999) and Heffelfinger (2006). We also obtained the bibliographical databases published in Mandujano (2004) and Gallina et al. (2008, 2009). Biogeographic models of physiographic regions and vegetation in Mexico were taken from Rzedowski and Reina-Trujillo (1990), Arriaga et al. (1997), Palacio et al. (2000) and Morrone (2005). Further, several digital maps of the 32 federal entities of Mexico (31 states and one Federal District; hereinafter 'states') were obtained from several sources, including: State Political Divisions of INEGI (National Institute of Statistics and Geography), Biogeographic Regions (Arriaga et al. 1997), National Forest Inventory (Palacio et al. 2000), and Floristic Divisions (Rzedowski and Reyna-Trujillo 1990). All of the maps on which this study was based were obtained from the databases if INEGI (http://mapserver.inegi.org.mx) and CONABIO (National Commision for the Understanding and Use of Biodiversity, http://www.conabio.gob.mx/informacion/gis/).

Analysis of geographic and statistical data.- The three distribution maps used were digitalised using Arc View ver. 3.2 (ESRI 1999) and homogenised into a plane coordinate system in order to simplify the area calculations into. The metadata used were from a map generated by CONABIO (http://www.conabio.gob.mx/informacion/). The resulting 
maps were geo-referenced to allow for simple, comparative referencing. Each of the distribution models was broken down into section by state and vegetation type, as mentioned earlier. Later, the areas of the different sections were calculated for each distribution model: the total area occupied by each subspecies, the area occupied by each subspecies in each state, and the area occupied by each subspecies in each vegetation type.

With the data we generated with regard to the area occupied by each subspecies within each vegetation type in each distribution model, we obtained percentages for each subspecies. With the percentage data for each vegetation type, we carried out Cluster Analyses (with the algorithm Euclidean Paired Group Similarity Index and Principal Component Analyses (PCA)), using correlation matrices and Euclidean Similarity Index for each distribution model using, in both cases, the statistics program PAST (Hammer et al. 2001). The results of both multivariate analyses allow related groups of subspecies, sharing similar vegetation types, to be defined. We defined these groups as possible ecoregions.

Based on the studies by Kellogg (1956) and Villarreal (2009), in Appendix 1. We show a description of the subspecies found in Mexico. However, it is important to note that the data presented are based on measurements taken from one, or just a few individuals. In the case of O. v. toltecus no data are available. We analysed the data from Appendix 1 using PCA with a correlation matrix, in order to know the relationships of the 13 Mexican subspecies (excluding O.v. toltecus, for which data was unavailable) in function of their size.

\section{Results}

Geographic distribution of subspecies.- The total distribution area for any given subspecies differed markedly, depending on the distribution model used (Table 1). The subspecies that differed in their distribution area, depending on the model were: O. v. carminis, O. v. oaxacensis, O. v. miquihuanensis, O. v. nelsoni, O. v. toltecus, O. v. veraecrucis and O. v. yucatanensis. If we do not consider the model used by Kellogg (1956), that underestimates distribution area, the subspecies with the greatest distribution area was O. v. couesi, which inhabits $>500,000 \mathrm{~km}^{2}$, followed by O. v. miquihuanensis ( 200,000 $\left.\mathrm{km}^{2}\right)$, O. v. sinaloae, O. v. mexicanus, O. v. texanus, and O. v. thomasi $(\sim 172,000$ to $\left.106,000 \mathrm{~km}^{2}\right)$. Other subspecies that varied between 60,000 and 106,000 $\mathrm{km}^{2}$ were: O v. carminis, O. v. veraecrucis, O. v. yucatanensis and O. v. acapulcensis. Finally, the remaining subspecies, O. $v$ truei, O. $v$ toltecus, O. v. oaxacensis, O. v. nelsoni, and were found to have the most restricted distribution areas $\left(<62,000 \mathrm{~km}^{2}\right)$.

Distribution by federal entity.- The number of subspecies that could apparently be found in each state (federal entity) varied depending on the distribution model used, primarily varying with the use of the Kellogg (1956) model, which could be considered overconservative (Table 2). The state with the greatest number of subspecies was Oaxaca, with 5 or 6 , followed by Durango, Guanajuato, Guerrero, Jalisco and Veracruz with 3 or 4. Those states that contained only one subspecies were: Distrito Federal, Estado de México, Morelos, Tabasco, Tlaxcala and Yucatán. Of the 30 states considered, only in 13 did the number of subspecies found coincide among the three models. In the case 
of the state of Aguascalientes, in Kellogg's (1956) model no subspecies are reported to be found because is considered problematic to define the geographic limits between subspecies (Fig. 1).

The subspecies that inhabited the greatest number of states was O. v. mexicanus (13 of

\begin{tabular}{lccc}
\hline Subspecies & \multicolumn{3}{c}{ Distribution Model } \\
\cline { 4 - 4 } & Kellogg+ & Hall & Villarreal \\
\hline O. v. acapulcensis & 66,014 & 69,248 & 64,077 \\
O. v. carminis & 26,315 & 94,031 & 102,390 \\
O. v. couesi & 451,518 & 548,802 & 528,928 \\
O. v. mexicanus & 121,544 & 171,574 & 143,697 \\
O. v. miquihuanensis & 94,250 & 175,221 & 223,362 \\
O. v. nelsoni & 38,142 & 40,500 & 27,750 \\
O. v. oaxacensis & 44,751 & 7,820 & 30,223 \\
O. v. sinaloae & 86,047 & 135,536 & 168,225 \\
O. v. texanus & 147,558 & 167,518 & 141,026 \\
O. v. thomasi & 76,939 & 105,737 & 117,363 \\
O. v. toltecus & 24,654 & 62,186 & 32,455 \\
O. v. truei & - & 26,378 & 46,189 \\
O. v. veraecrucis & 37,296 & 76,257 & 95,505 \\
O. v. yucatanensis & 127,965 & 84,612 & 71,753 \\
\hline
\end{tabular}

Table 1. Surface $\left(\mathrm{km}^{2}\right)$ occupied by each of the white-tailed deer subspecies, depending on the distribution model used. + According with the delimitation of the geographic distribution of each subspecies, this model sub-estimated the distribution surface for some subspecies; see text.

30, including Distrito Federal), followed by O. v. couesi, O. v. miquihuanensis and $O$. v. sinaloae. The only subspecies limited to just one state was O. v. nelsoni; while O. v. oaxacensis and O. v. truei were limited to two states (Fig. 1). Although we do not present the data, given the differences in the distribution of subspecies between models, the area inhabited by each subspecies in each state varied considerably.

Distribution by vegetation type.- It is important to note that of the 14 subspecies found in Mexico, only two (O. v. texanus and O. v. carminis) did not inhabit tropical forests; while all of the other 12 subspecies included at least some tropical forest within their distribution areas (Fig. 2 and Table 3). The subspecies O. v. miquihuanensis and O. $v$. couesi, considered to be principally found in shrub land and temperate forest respectively, were also found to marginally inhabit dry tropical forests. However, those subspecies with a greater part of their total distribution area occupied by deciduous or tropical dry forests were: O. v. sinaloae, O. v. mexicanus, O. v. acapulcensis and O. v. yucatanensis. In contrast, the subspecies O. v. veraecrucis, O. v. toltecus, O. v. thomasi, O. v. nelsoni and $O$. v. truei, inhabited tropical evergreen forest, tropical semi-deciduous forest and cloud forest. 
Table 2. Distribution of the white-tailed deer subspecies in each state or federal entity in Mexico. + In these states, the number of subspecies is the same in the three models used

\begin{tabular}{|c|c|c|c|}
\hline \multirow{2}{*}{ State } & \multicolumn{3}{|c|}{ Distribution model } \\
\hline & Kellogg & Hall & Villarreal \\
\hline Aguascalientes & & cou, miq & cou, miq \\
\hline Campeche & tho, yuc & tho, tru, yuc & tho, tru, yuc \\
\hline Chiapas+ & nel, tho & nel, tho & nel, tho \\
\hline Chihuahua+ & car, cou, tex & car, cou, tex & car, cou, tex \\
\hline Coahuila & car, cou, miq, tex & car, miq, tex & car, miq, tex \\
\hline Colima & aca, sin & aca, sin & $\sin$ \\
\hline Distrito Federal+ & $\operatorname{mex}$ & mex & $\operatorname{mex}$ \\
\hline Durango & cou, sin & car, cou, miq, sin & car, cou, miq, sin \\
\hline Guanajuato & $\operatorname{mex}$ & cou, mex, miq, sin & cou, mex, miq, sin \\
\hline Guerrero & aca, mex, oax & aca, mex, sin & aca, mex, oax, sin \\
\hline Hidalgo & $\operatorname{mex}$ & mex, ver & mex, ver \\
\hline Jalisco & aca, cou, mex, sin & aca, cou, miq, sin & cou, miq, sin \\
\hline México+ & $\operatorname{mex}$ & $\operatorname{mex}$ & $\operatorname{mex}$ \\
\hline Michoacán+ & aca, mex, sin & aca, mex, sin & aca, mex, sin \\
\hline Morelos+ & $\operatorname{mex}$ & mex & $\operatorname{mex}$ \\
\hline Nayarit & $\sin$ & cou, sin & cou, sin \\
\hline Nuevo León+ & miq, tex & miq, tex & miq, tex \\
\hline Oaxaca & aca, oax, tho, tol & $\begin{array}{l}\text { aca, mex, oax, tho, } \\
\text { tol }\end{array}$ & aca, mex, oax, tho, tol, ver \\
\hline Puebla & mex, oax, tol, ver & mex, tol, ver & mex, tol, ver \\
\hline Querétaro & $\operatorname{mex}$ & mex, ver & mex, miq, ver \\
\hline Quintana Roo & yuc & tru, yuc & tru, yuc \\
\hline San Luis Potosí & mex, miq & mex, miq, ver & mex, miq, ver \\
\hline Sinaloa+ & cou, sin & $\mathrm{cou}, \sin$ & cou, sin \\
\hline Sonora & $\mathrm{cou}$ & $\mathrm{cou}$ & cou, sin \\
\hline Tabasco+ & tho & tho & tho \\
\hline Tamaulipas+ & miq, tex, ver & miq, tex, ver & miq, tex, ver \\
\hline Tlaxcala+ & $\operatorname{mex}$ & mex & mex \\
\hline Veracruz & tho, tol, ver & mex, tho, tol, ver & mex, tho, tol, ver \\
\hline Yucatán+ & yuc & yuc & yuc \\
\hline Zacatecas+ & cou, miq & cou, miq & cou, miq \\
\hline
\end{tabular}

Groups of subspecies by vegetation type.- Both PCA (Fig. 3) and Cluster Analysis (Fig. 4) gave similar results for all three distribution models. In general, PCA revealed a clear order of the subspecies O. v. texanus, O. v. miquihuanensis, O. v. carminis and O. v. couesi in function with the presence of shrub land in the north of Mexico; although O. v. couesi is more clearly associated with temperate forests. The subspecies O. $v$. mexicanus, O. v. sinaloae, O. v. oaxacensis and O. v. acapulcensis formed a group associated with temperate pine-oak forest and tropical dry forest, mostly in the Pacific region and the centre of the country. The subspecies O. v. veraecrucis, O. v. thomasi, $O$. 

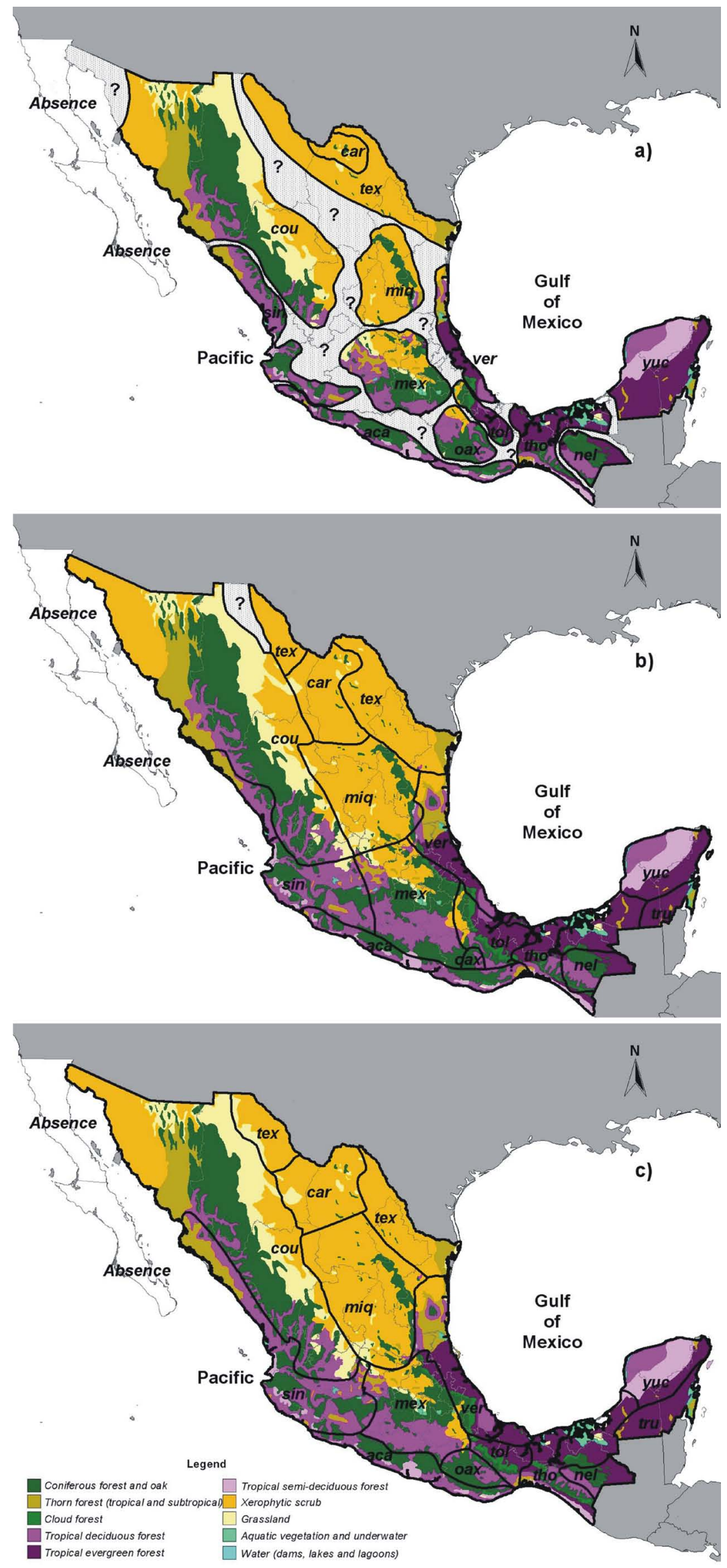

a).-Kellogg model

b).-Hall model

c).-Villarreal model

Figure 2. Distribution models of the whitetailed deer subspecies in Mexico within the principal vegetation types proposed by Rzedowski and ReynaTrujillo (1990). 
Table 3. Distribution potential $\left(\mathrm{km}^{2}\right)$ of the white-tailed deer subspeceis in each of the vegetation types by Rzedowski and ReynaTrujillo (1990) and modified by CONABIO.

\begin{tabular}{|c|c|c|c|c|}
\hline \multirow[b]{2}{*}{ Subspecies } & \multirow[b]{2}{*}{ Vegetation types } & \multicolumn{3}{|c|}{ Distribution model } \\
\hline & & Kellogg & Hall & Villarreal \\
\hline $\begin{array}{l}\text { O. v. } \\
\text { acapulcensis }\end{array}$ & $\begin{array}{l}\text { Temperate forest } \\
\text { Thorn forest } \\
\text { Cloud forest } \\
\text { Tropical dry forest } \\
\text { Tropical semi-deciduous forest } \\
\text { Tropical rainforest } \\
\text { Grassland } \\
\text { Shrub land } \\
\text { Aquatic vegetation }\end{array}$ & $\begin{array}{r}26,038 \\
969 \\
1,221 \\
26,874 \\
10,002 \\
- \\
207 \\
- \\
-\end{array}$ & $\begin{array}{r}26,592 \\
2,408 \\
1,225 \\
28,986 \\
8,691 \\
312 \\
- \\
-\end{array}$ & $\begin{array}{r}29,751 \\
156 \\
1,221 \\
23,692 \\
8,894 \\
- \\
384 \\
-\end{array}$ \\
\hline O. v. carminis & $\begin{array}{l}\text { Temperate forest } \\
\text { Thorn forest } \\
\text { Cloud forest } \\
\text { Tropical dry forest } \\
\text { Tropical semi-deciduous forest } \\
\text { Tropical rainforest } \\
\text { Grassland } \\
\text { Shrub land } \\
\text { Aquatic vegetation }\end{array}$ & $\begin{array}{r}783 \\
- \\
- \\
- \\
- \\
1,037 \\
24,444 \\
-\end{array}$ & $\begin{array}{r}1,429 \\
- \\
- \\
- \\
- \\
4,107 \\
88,487 \\
-\end{array}$ & $\begin{array}{r}1,585 \\
- \\
- \\
- \\
- \\
- \\
7,021 \\
93,359 \\
-\end{array}$ \\
\hline O. v. couesi & $\begin{array}{l}\text { Temperate forest } \\
\text { Thorn forest } \\
\text { Cloud forest } \\
\text { Tropical dry forest } \\
\text { Tropical semi-deciduous forest } \\
\text { Tropical rainforiest } \\
\text { Grassland } \\
\text { Shrub land } \\
\text { Aquatic vegetation }\end{array}$ & $\begin{array}{r}146,339 \\
57,047 \\
31,342 \\
- \\
- \\
100,917 \\
115,426 \\
-\end{array}$ & $\begin{array}{r}173,891 \\
56,989 \\
57,725 \\
- \\
- \\
110,364 \\
149,177 \\
-\end{array}$ & $\begin{array}{r}173,912 \\
42,842 \\
- \\
46,453 \\
- \\
- \\
120,832 \\
143,746\end{array}$ \\
\hline $\begin{array}{l}\text { O. v. } \\
\text { mexicanus }\end{array}$ & $\begin{array}{l}\text { Temperate forest } \\
\text { Thorn forest } \\
\text { Cloud forest } \\
\text { Tropical dry forest } \\
\text { Tropical semi-deciduous forest } \\
\text { Tropical rainforest } \\
\text { Grassland } \\
\text { Shrub land } \\
\text { Aquatic vegetation }\end{array}$ & $\begin{array}{r}41,525 \\
7,461 \\
614 \\
30,406 \\
- \\
658 \\
9,601 \\
29,139 \\
2,140\end{array}$ & $\begin{array}{r}66,415 \\
6,501 \\
1,970 \\
55,707 \\
811 \\
4,183 \\
4,833 \\
28,955 \\
2,198\end{array}$ & $\begin{array}{r}46,190 \\
4,592 \\
1,738 \\
53,063 \\
5,680 \\
3,995 \\
26,195 \\
2,245\end{array}$ \\
\hline $\begin{array}{l}\text { O. v. } \\
\text { miquihuanensis }\end{array}$ & $\begin{array}{l}\text { Temperate forest } \\
\text { Thorn forest } \\
\text { Cloud forest } \\
\text { Tropical dry forest } \\
\text { Tropical semi-deciduous forest } \\
\text { Tropical rainforest } \\
\text { Grassland } \\
\text { Shrub land } \\
\text { Aquatic vegetation }\end{array}$ & $\begin{array}{r}14,841 \\
- \\
- \\
- \\
- \\
1,783 \\
77,626 \\
-\end{array}$ & $\begin{array}{r}18,259 \\
1,608 \\
142 \\
2,038 \\
350 \\
- \\
12,839 \\
139,986 \\
-\end{array}$ & $\begin{array}{r}20,598 \\
375 \\
136 \\
1,014 \\
188 \\
- \\
7,881 \\
193,169\end{array}$ \\
\hline O. v. nelsoni & $\begin{array}{l}\text { Temperate forest } \\
\text { Thorn forest } \\
\text { Cloud forest } \\
\text { Tropical dry forest } \\
\text { Tropical semi-deciduous forest } \\
\text { Tropical rainforest } \\
\text { Grassland } \\
\text { Shrub land } \\
\text { Aquatic vegetation }\end{array}$ & $\begin{array}{r}15,091 \\
1,279 \\
9,850 \\
11,922 \\
- \\
-\end{array}$ & $\begin{array}{r}15,814 \\
9- \\
949 \\
10,749 \\
24 \\
12,747 \\
- \\
-\end{array}$ & $\begin{array}{r}8,958 \\
192 \\
6,950 \\
11,911 \\
- \\
-\end{array}$ \\
\hline $\begin{array}{l}\text { O. v. } \\
\text { oaxacensis }\end{array}$ & $\begin{array}{l}\text { Temperate forest } \\
\text { Thorn forest } \\
\text { Cloud forest } \\
\text { Tropical dry forest } \\
\text { Tropical semi-deciduous forest } \\
\text { Tropical rainforest } \\
\text { Grassland } \\
\text { Shrub land } \\
\text { Aquatic vegetation }\end{array}$ & $\begin{array}{r}20,823 \\
1,029 \\
17,526 \\
221 \\
199 \\
4,953 \\
-\end{array}$ & $\begin{array}{r}5,232 \\
- \\
- \\
2,483 \\
- \\
- \\
- \\
-\end{array}$ & $\begin{array}{r}20,313 \\
16 \\
196 \\
9,495 \\
- \\
- \\
37 \\
166 \\
-\end{array}$ \\
\hline
\end{tabular}


continuación Tabla $3 .$.

Distribution model

Kellogg Hall Villarreal

\begin{tabular}{|c|c|c|c|c|}
\hline O. v. sinaloae & $\begin{array}{l}\text { Temperate forest } \\
\text { Thorn forest } \\
\text { Cloud forest } \\
\text { Tropical dry forest } \\
\text { Tropical semi-deciduous forest } \\
\text { Tropical rainforest } \\
\text { Grassland } \\
\text { Shrub land } \\
\text { Aquatic vegetation }\end{array}$ & $\begin{array}{r}27,647 \\
9,584 \\
668 \\
41,443 \\
4,984 \\
- \\
- \\
1,182\end{array}$ & $\begin{array}{r}39,765 \\
12,455 \\
683 \\
70,861 \\
6,221 \\
2,854 \\
1,996\end{array}$ & $\begin{array}{r}43,082 \\
29,633 \\
684 \\
85,208 \\
6,862 \\
784 \\
- \\
2,279\end{array}$ \\
\hline O. v. texanus & $\begin{array}{l}\text { Temperate forest } \\
\text { Thorn forest } \\
\text { Cloud forest } \\
\text { Tropical dry forest } \\
\text { Tropical semi-deciduous forest } \\
\text { Tropical rainforest } \\
\text { Grassland } \\
\text { Shrub land } \\
\text { Aquatic vegetation }\end{array}$ & $\begin{array}{r}903 \\
7,239 \\
- \\
- \\
- \\
- \\
2,980 \\
135,504 \\
-\end{array}$ & $\begin{array}{r}1,111 \\
8,820 \\
237 \\
- \\
- \\
2,787 \\
153,911 \\
-\end{array}$ & $\begin{array}{r}439 \\
8,426 \\
- \\
- \\
- \\
- \\
12,960 \\
117,857\end{array}$ \\
\hline O. v. thomasi & $\begin{array}{l}\text { Temperate forest } \\
\text { Thorn forest } \\
\text { Cloud forest } \\
\text { Tropical dry forest } \\
\text { Tropical semi-deciduous forest } \\
\text { Tropical rainforest } \\
\text { Grassland } \\
\text { Shrub land } \\
\text { Aquatic vegetation }\end{array}$ & $\begin{array}{r}5,240 \\
1,544 \\
2,130 \\
5,353 \\
4,725 \\
41,739 \\
2,441 \\
11,814\end{array}$ & $\begin{array}{r}6,713 \\
1,951 \\
3,675 \\
5,687 \\
4,998 \\
65,725 \\
2,844 \\
11,791\end{array}$ & $\begin{array}{r}13,501 \\
2,160 \\
3,724 \\
9,766 \\
8,092 \\
65,134 \\
2,932 \\
12,183\end{array}$ \\
\hline O. v. toltecus & $\begin{array}{l}\text { Temperate forest } \\
\text { Thorn forest } \\
\text { Cloud forest } \\
\text { Tropical dry forest } \\
\text { Tropical semi-deciduous forest } \\
\text { Tropical rainforest } \\
\text { Grassland } \\
\text { Shrub land } \\
\text { Aquatic vegetation }\end{array}$ & $\begin{array}{r}4,419 \\
- \\
3,441 \\
1,000 \\
- \\
13,667 \\
1,919 \\
208\end{array}$ & $\begin{array}{r}13,601 \\
- \\
7,556 \\
7,789 \\
- \\
26,767 \\
- \\
6,270 \\
202\end{array}$ & $\begin{array}{r}5,161 \\
826 \\
5,551 \\
4,136 \\
16,768 \\
- \\
12\end{array}$ \\
\hline O. v. truei & $\begin{array}{l}\text { Temperate forest } \\
\text { Thorn forest } \\
\text { Cloud forest } \\
\text { Tropical dry forest } \\
\text { Tropical semi-deciduous forest } \\
\text { Tropical rainforest } \\
\text { Grassland } \\
\text { Shrub land } \\
\text { Aquatic vegetation }\end{array}$ & $\begin{array}{l}- \\
- \\
- \\
- \\
- \\
- \\
- \\
-\end{array}$ & $\begin{array}{r}2,222 \\
430 \\
- \\
19,924 \\
- \\
- \\
1,876\end{array}$ & $\begin{array}{r}49,482 \\
- \\
- \\
39,729 \\
- \\
881\end{array}$ \\
\hline $\begin{array}{l}\text { O. v. } \\
\text { veraecrucis }\end{array}$ & $\begin{array}{l}\text { Temperate forest } \\
\text { Thorn forest } \\
\text { Cloud forest } \\
\text { Tropical dry forest } \\
\text { Tropical semi-deciduous forest } \\
\text { Tropical rainforest } \\
\text { Grassland } \\
\text { Shrub land } \\
\text { Aquatic vegetation }\end{array}$ & $\begin{array}{r}800 \\
6,835 \\
1,619 \\
7,248 \\
17,302 \\
657 \\
1,616 \\
816\end{array}$ & $\begin{array}{r}3,751 \\
17,268 \\
1,524 \\
13,140 \\
123 \\
28,339 \\
674 \\
9,597 \\
1,123\end{array}$ & $\begin{array}{r}9,109 \\
18,934 \\
4,390 \\
16,869 \\
284 \\
31,293 \\
970 \\
12,953 \\
1,048\end{array}$ \\
\hline $\begin{array}{l}\text { O. v. } \\
\text { yucatanensis }\end{array}$ & $\begin{array}{l}\text { Temperate forest } \\
\text { Thorn forest } \\
\text { Cloud forest } \\
\text { Tropical dry forest } \\
\text { Tropical semi-deciduous forest } \\
\text { Tropical rainforest } \\
\text { Grassland } \\
\text { Shrub land } \\
\text { Aquatic vegetation }\end{array}$ & $\begin{array}{r}4,533 \\
- \\
16,230 \\
33,509 \\
67,228 \\
50 \\
- \\
3,838\end{array}$ & $\begin{array}{r}859 \\
- \\
16,018 \\
33,104 \\
31,709 \\
- \\
- \\
1,800\end{array}$ & $\begin{array}{r}762 \\
- \\
18,240 \\
31,733 \\
21,401\end{array}$ \\
\hline
\end{tabular}


v. toltecus, O. v. truei and O. v. yucatanensis are associated with tropical rain forest, semideciduous forest, cloud forest, thorn forest and aquatic and sub-aquatic vegetation in the southeast. Finally, the subspecies $O$. v. nelsoni was an intermediate subspecies between the temperate and dry forest group and the tropical rainforest and semi-deciduous group. With slight variations, this tendency was observed in all three models (Fig. 3).

Cluster Analysis revealed similar groups of subspecies, with slight differences. The main difference being that O. v. couesi was associated with the temperate/dry forest group, depending on the distribution model used (Fig. 4). Consequently, both PCA and Cluster Analysis defined three distinct groups of subspecies, clearly associated with vegetation types. This classification into three groups can be considered as a proposal for distinct ecoregions, or possible ecotypes for white-tailed deer in Mexico: the ecoregion that includes the shrub land of the northeast; that which includes the temperate forests and tropical dry forests of the Pacific and central country; and that which includes the tropical rain forests, semi-deciduous forests and cloud forests of the Gulf and southeast of the country.

Size of subspecies.- Analysis by PCA demonstrated that 13 of the 14 subspecies found in Mexico (excluding O. v. toltecus, for which data was unavailable) can be organised by size, based on total length, chest height and antler measurement (Fig. 5). The largest subspecies was $O$. v. texanus, followed by O. v. carminis, O. v. miquihuanensis, $O$. v. veraecrucis, O. v. mexicanus and $O$. v. couesi; while the smallest subspecies were O. v. sinaloae, O. v. thomasi, O. v. yucatanensis, O. v. truei, O. v. oaxacensis, O. v. acapulcensis and O. v. nelsoni.

\section{Discussion}

Biological implications.- The maps, or distribution models, proposed by Kellogg (1956), more than 50 years ago, Hall (1981), which was widely accepted, and Villarreal (1999), which is the most commonly used map in Mexico, are not exempt from errors in their definitions of the biogeographical limits between subspecies. To reduce this, Kellogg (1956) presented distribution areas in which the geographical limits between subspecies were discontinuous. In contrast, Hall (1981) extended the geographic distribution of each subspecies and proposed clearly defined limits. However, these limits were defined on the basis of the author's own criteria and not necessarily on the basis of quantitative studies. Further, this author recognised a fourteenth subspecies, O. v. truei (= nemoralis), located in the southeast of the country. Another important difference between the models is that Hall (1981) significantly increased the distribution area of O. v. carminis, which Kellogg (1956) reported as found only in a highly restricted area of the Sierra del Carmen, Coahuila. Morphometric studies of O. v. carminis by Krausman et al. (1978) confirmed the difference with other subspecies; but its geographical limits its unknown. By increasing the distribution area, Hall (1981) introduced this subspecies into areas of shrub land, where O. v. texanus and O. v. miquihuanensis were also found. Another difference between the models is that, while Kellogg (1956) presents a wide-ranging distribution area for O. v. oaxacensis, Hall (1981) reduces this distribution to a very small area of the Valles Centrales of Oaxaca. This means that distinguishing O. v. oaxacensis from O. v. toltecus can be complicated and their areas of sympatry can be hard to define. 

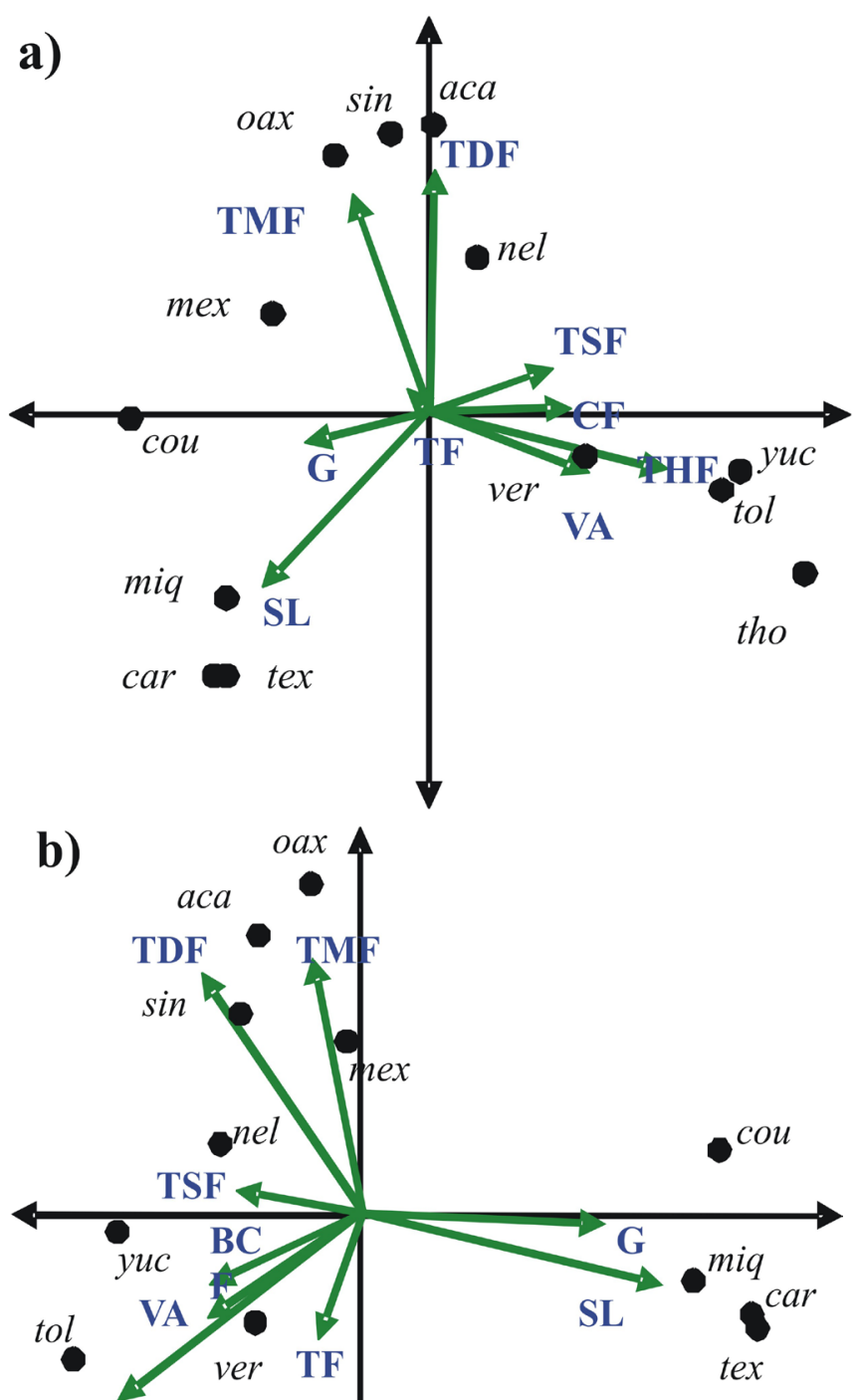

Hall model

Kellogg model
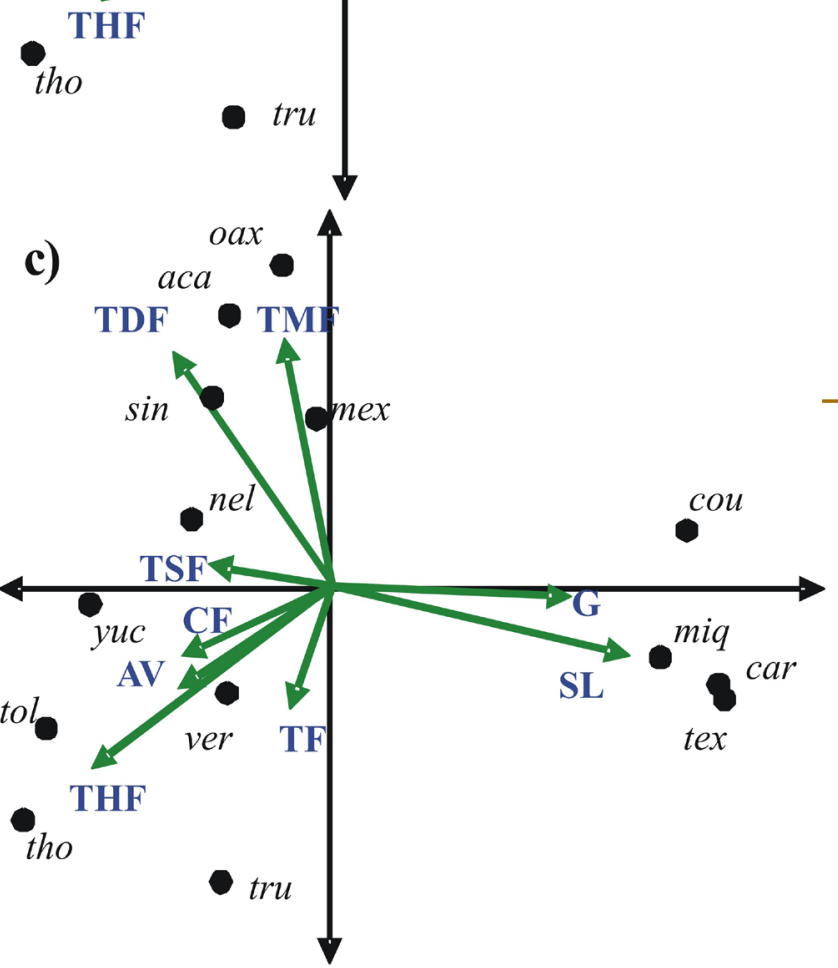

Figure 3. Ordination of the subspecies of whitetailed deer in function with vegetation type for each of the three distribution models. The variation explained by the first two principal components were $53.4 \%, \quad 53.2 \%$ and $54.04 \%$ for the Kellogg, Hall and Villarreal models, respectively. Abbreviations: shrub land $(\mathrm{SL})$, grassland $(\mathrm{G})$, temperate mixed forest (TMF), tropical dry forest (TDF), tropical humid forest (THF), tropical semi-deciduous forest (TSF), cloud forest (CF), thorn forest (TF), semiaquatic vegetation (AV). 
Kellogg model

Hall model

Villarreal model

Figure 4. Classification of the subspecies of white-tailed deer in function with vegetation type for each of the three distribution models, following the algorithm Euclidean Paired Group Similarity Index. The coefficients of correlation were $0.93,0.91$ and 0.87 for the Kellogg, Hall and Villarreal models, respectively.
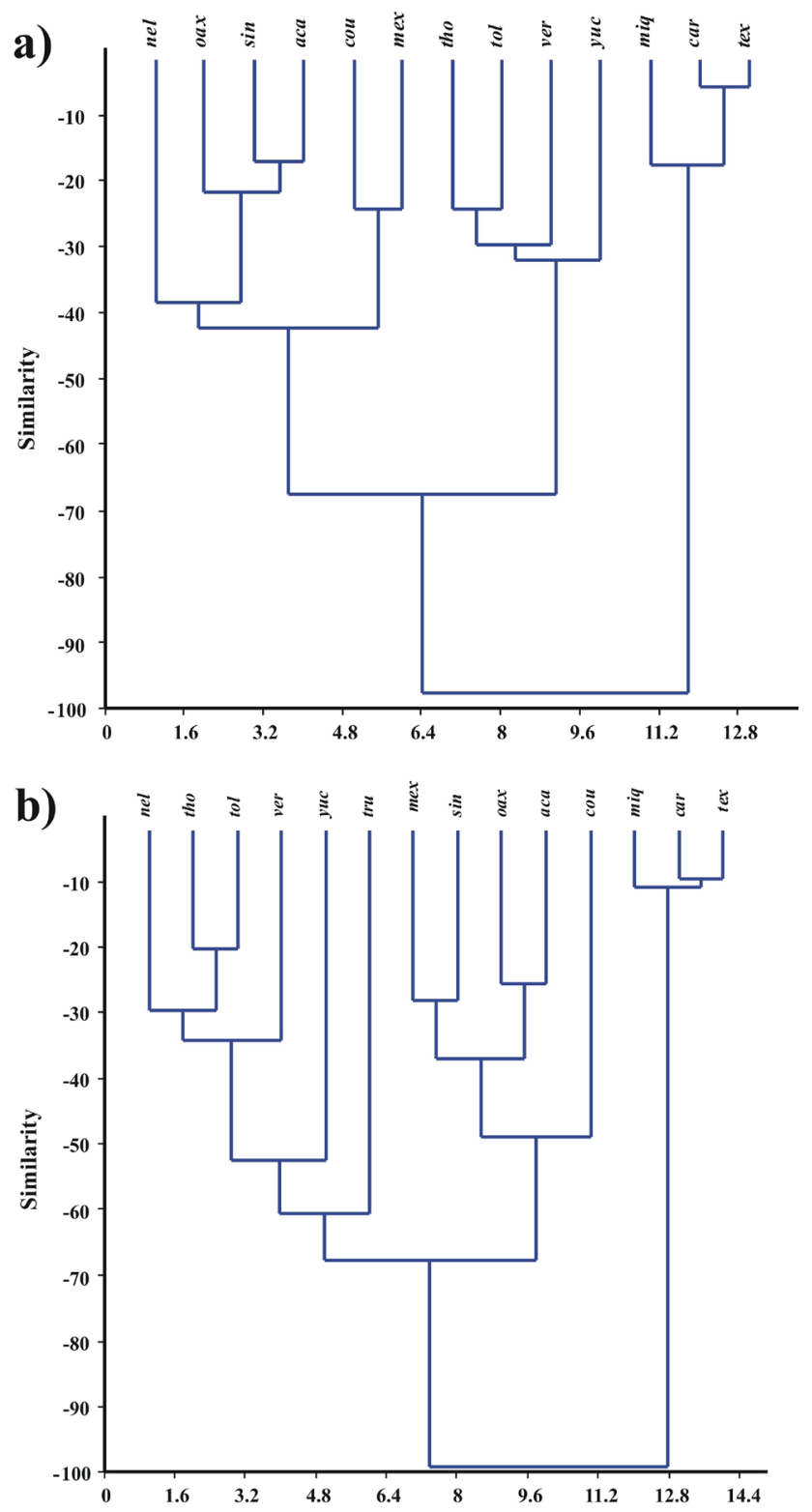

c)

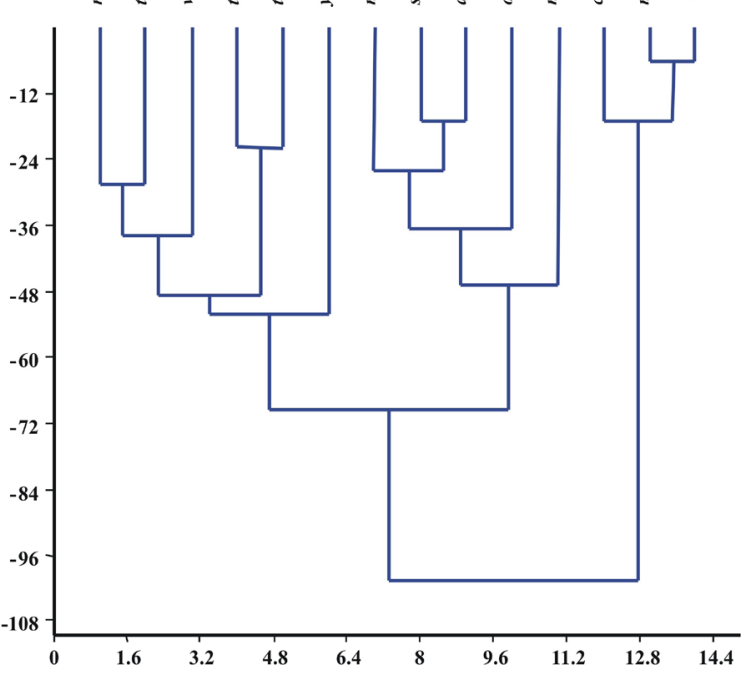


For example, Ortiz-Martínez et al. (2005) and Briones and García (2005) identify O. v. oaxacensis for the north of the state of Oaxaca. The map proposed by Villarreal (1999) identifies 14 subspecies, but modifies their distribution limits. For example, in the case of $O$. v. oaxacensis important changes are made, while the distribution of O. v. sinaloae is extended to the south of Sonora and the distribution limits are modified for $O$. v. texanus, O. v. miquihuanensis and O. v. carminis (Fig. 1). These differences among distribution models were evident when we estimate the area of distribution at national and federal state level (Table 2). In some cases, even the number of subspecies by federal entity was different depending of the model used (Table 1). Also, these differences are evident in the vegetation type occupied by each subspecies (Table 3).

From an ecological perspective, our results suggests that the 14 subspecies can be grouped into three ecoregions: north-eastern shrub land (O. v. carminis, O. $v$. miquihuanensis and O. v. texanus), Pacific and central temperate and tropical dry forests (, O. v. acapulcensis, O. v. couesi, O. v. mexicanus, O. v. oaxacensis and O. v. sinaloae,), and Gulf-southeast tropical humid, sub-deciduous and cloud forests (O. v. nelsoni, O. $v$. thomasi, O. v. toltecus, O. v. truei, O. v. veraecrucis and O. v. yucatanensis). An ecoregion is defined as a relatively large area of land or water that contains a geographically distinct assemblage of natural communities and environmental conditions (WWF 1999). These communities share a large majority of their species, dynamics, and environmental conditions, and function together effectively as a conservation unit at global and continental scales (Dinerstein et al. 1995). Several standard methods of classifying ecoregions have been developed, with climate, altitude, and predominant vegetation being important criteria (Olson et al. 2001). Because ecoregions are defined by their shared biotic and abiotic characteristics, they represent practical units on which to base conservation planning. For example, a map of Mexican ecoregions was presented by Dinerstain et al. (1995).

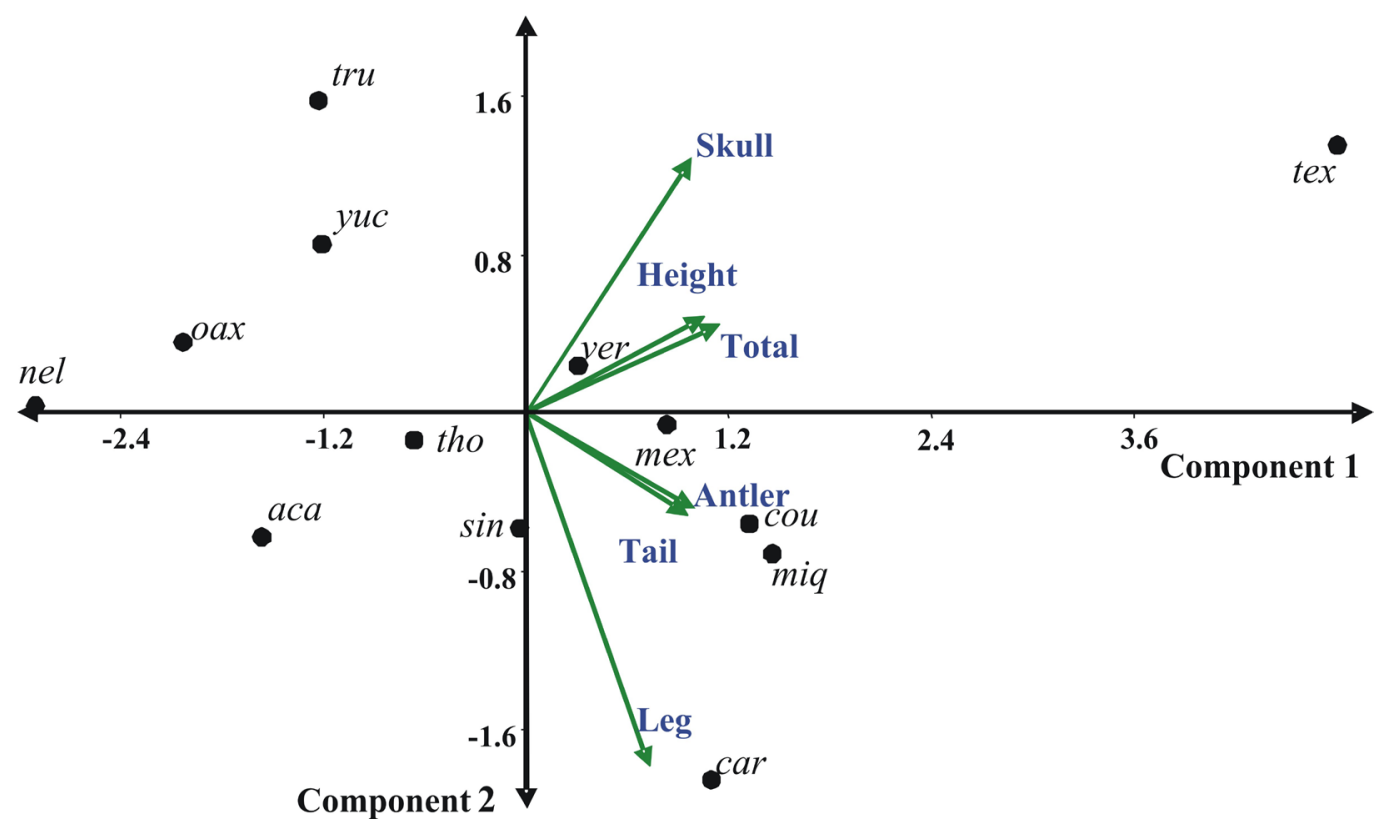

Figure 5. Ordination of the white-tailed deer subspecies in Mexico in function with the morphological characteristics described in Table 1. The variation explained by the first two principal components was $79.9 \%$. The first component $(60 \%)$ characterises, in the right side of the graph, those subspecies of greater size expressed as the total length (total), height of shoulder (height) and antler size (antler). 
The use of ecoregions for deer classification and management has also been suggested for mule deer (Heffelfinger et al. 2006). The 11 subspecies of mule deer and black-tailed deer are distributed throughout western United States and the northern Mexican states. With this wide latitudinal and geographic range, mule deer occupy a great diversity of climatic regimes and vegetation associations, resulting in an incredibly diverse set of behavioural and ecological adaptations that have allowed this species to succeed. Within the geographic distribution of mule deer, however, areas can be grouped together into ecoregions, within which deer populations share certain similarities. With regard to the issues and challenges that deer managers face, deVos et al. (2003) has designated seven separate ecoregions: California Woodland Chaparral, Colorado Plateau Shrubland and Forest, Coastal Rain Forest, Great Plains, Intermountain West, Northern Boreal Forest, and Southwest Deserts. The diversity among the ecoregions presents different challenges to deer managers and guidelines for managing habitat must address these differences (Heffelfinger et al. 2003).

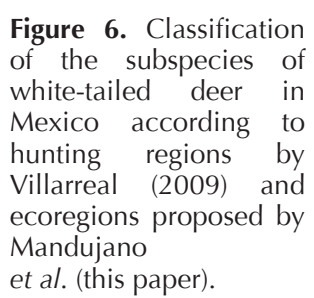

et al. (this paper).

\begin{tabular}{|c|c|c|}
\hline Subspecies & Hunting regions & Ecoregions \\
\hline $\begin{array}{l}\text { O. v. texanus } \\
\text { O. v. carminis } \\
\text { O. v. miquihuanensis }\end{array}$ & $\begin{array}{l}\text { Texas white-tailed deer } \\
\text { Carminis white-tailed deer } \\
\text { Chihuahuan Desert white tailed deer }\end{array}$ & Northeastern shrub lands \\
\hline $\begin{array}{l}\text { O. v. couesi } \\
\text { O. v. sinaloae } \\
\text { O. v. acapulcensis } \\
\text { O. v. mexicanus } \\
\text { O. } v \text { oaxacensis }\end{array}$ & $\begin{array}{l}\text { Coues white-tailed deer } \\
\text { North Pacific white-tailed deer } \\
\text { South Pacific white-tailed deer } \\
\text { Mexican white-tailed deer }\end{array}$ & $\begin{array}{l}\text { Pacific and Central temperate } \\
\text { and tropical dry forests }\end{array}$ \\
\hline $\begin{array}{l}\text { O. v. toltecus } \\
\text { O. v. thomasi } \\
\text { O. v. nelsoni } \\
\text { O. v. truei } \\
\text { O. v. yucatanensis } \\
\text { O. v. veraecrucis }\end{array}$ & $\begin{array}{l}\text { Southeastern white-tailed deer } \\
\text { Gulf white-tailed deer }\end{array}$ & $\begin{array}{l}\text { Southeastern and Gulf tropical } \\
\text { humid, semi-deciduous and } \\
\text { cloud forests }\end{array}$ \\
\hline
\end{tabular}

For the distribution of white-tailed deer subspecies in the United States, Deckman (2003) classified the 16 subspecies into six regions: Western Region I (O. v. couesi, O. v. leucurus, and O. v. ochrourus). North Central Region II (O. v. dacotensis). Central Plains Region III (O. v. macrourus and O. v. texanus). Gulf Coast Region IV (O. v. clavium, O. v. mcilhennyi, O. v. osceola and O. v. seminolus). Atlantic Islands and Southeastern Region $\vee(O . v$. hiltonensis, O. v. nigribarbis, O. v. taurinsulae, O. v. venatorius and $O$. v. virginianus), and Northeastern Region VI (O. v. borealis). However, this author also recognised that white-tailed deer subspecies could overlap in many areas and that the genetic pool in these areas is likely to be mixed.

For Mexico, the Comisión de Flora y Fauna Silvestres de Nuevo León (CEFFSNL) recently proposed to Safari Club International the inclusion of nine hunting regions, with the objective of recognising all of the 14 different subspecies of white-tailed deer in Mexico on an international scale as different sport hunting trophies (Villarreal 2009). This proposal comes from the fact that the Safari Club International and Boone and Crockett 
Club only recognise five subspecies. The hunting regions were defined on the basis of antler size, in such as way that males of the different subspecies are competitive within any given geographic region with particular ecological characteristics. The hunting regions proposed by Villarreal (2009) are presented in figure 6, in which we also compare the classification of the ecoregions proposed in this article. This figure represents a synthesis of both hunting and ecological view of the 14 subspecies in Mexico, and we propose it as a framework for management and conservation actions.

The taxonomic rank of subspecies has been the subject of long-running controversy (Mayr 1982). Traditionally, subspecies have been recognised on the basis of discontinuities in the geographical distribution of phenotypic traits. It has long been established that populations on islands encounter a physical impediment to gene-flow between local populations, and it is therefore expected that such populations may diverge in isolation (Mayr and Ashlock 1991). In contrast, continental subspecies will often have geographical ranges that directly adjoin, or even overlap, those of conspecific subspecies, and thus any phenotypic adaptation to local environments will need to take place in the face of gene flow (e. g., ecotype). Throughout the geographic range of white-tailed deer in Mexico, we see a lot of variation in body size, pelage colour, antler shape, and other attributes (Kellogg 1956, Villarreal 2009). For example, subspecies in the southern latitudes are generally smaller in body size than those in the north, and those inhabiting open habitats appear lighter in colour than those in heavily forested habitats. As was the case with mule deer O. hemionus (Heffelfinger 2006), the geographic range of several white-tailed deer subspecies was drawn somewhat arbitrarily. In fact, the purported differences between subspecies were often based on subjective opinions regarding characteristics or measurements of only one or a few specimens. Fortunately, recent advances in DNA analysis techniques now allow researchers to evaluate genetic data in ways that provide managers with meaningful ecological management units on an ecoregion scale. Therefore, given the lack of quantitative morphometric and genetic data for the subspecies, it is impossible to confirm the taxonomic validity of the subspecies present in the country. Further, the absence of phylogeographic studies means that the redefinition of the geographic limits between subspecies is not possible. Indeed, when faced with a species with such capacity for adaptation to different environments, it is hard to define where the distribution of one subspecies ends and another begins (i.e., zones of sympatry) as, basically, some kind of geographic (mountains, rivers, drastic changes in vegetation type) or climatic barrier ought to exist in order to clearly define subspecies. However, in some cases we may expect to find a gradient of variations, or cline, from one subspecies to the next and, therefore, the distribution limits between them become arbitrary.

Management implications.- Given the lack of data supporting the validity of the biogeographic limits of the subspecies, there should be strict control over the deliberate, or even accidental, movement of subspecies to localities where they have not been historically reported. One important problem is posed by those regions where more than one subspecies converge and the criteria to define the geographic limits between the subspecies are arbitrary. The translocation of animal species has resulted in severe consequences for conservation, such as interspecific competition and the introduction of 
diseases and parasites (Waldrup et al. 1990; Kock et al. 2007). For example, Galindo and Weber (1994) reported incidences of dystocia (difficulty in parturition), probably caused by the translocation of some individuals of other subspecies, such as $O$. v. texanus, into the distribution range of O. v. couesi, in La Michilía, Durango. Unfortunately, some programmes translocate individuals, principally of the subspecies $O$. $v$. texanus, to other parts of the country, with the idea of "improving the breed", mainly the size of their antlers. In such a case, Storfer (1999) suggested that knowledge of gene flow rates and understanding ecological differences among populations is necessary before embarking on a program to artificially enhance gene flow. This situation could change in the medium term. For example, recently, the CEFFSNL stated that although they had always supported and developed cynegetic activities for the benefit of the economy, they would not agree to support the transfer of individuals of the subspecies O. v. texanus from the north of Mexico (Coahuila, Nuevo León and Tamaulipas) to other parts of the country, even under regulated management schemes such as in UMAs. This is to avoid cross breading between subspecies that are adapted to differing ecological conditions and that form part of the biological heritage of the country (Villarreal 2009). Our classification of the 14 subspecies into three possible ecoregions suggests the more critical action to translocate deer among ecoregions than inside of the same ecoregion. Ecoregions classification implicates a local adaptation to similar ecological conditions.

From a conservation perspective, Phillimore and Owens (2006) suggest that subspecies may be of considerable conservation value, as proxies for the sub-structure found within species. They suggest that the conservation value of subspecies is likely to be greatest in situations where molecular data is absent, a scenario that is encountered in the white-tailed deer in Mexico. However, there is an urgent need to integrate biographic models and molecular studies (e. g., Moodley and Bruford 2007) as a framework for the conservation of white-tailed deer at the national and continental scale. Thus, it is imperative to obtain data on the geographical variation of white-tailed deer throughout the country. The studies must investigate both morphological and genetic variation. This evaluation will provide not only a basis for conservation efforts (Gallina and Mandujano 2009), but also help solidify the range of different subspecies into and among ecoregions. Clear delineation of the boundary among subspecies is an issue that the governmental offices (SEMARNAT, DGVS, CONANP, CONABIO) and international agencies such as Safari Club International must address in order to maintain the integrity of the different geographical haplotypes and for trophy record books.

\section{Acknowledgements}

We are grateful to the editor T. Álvarez for the invitation to contribute in this inaugural edition of the journal Theyra. T. Pérez kindly helped with the organisation of the tables. To J, A. Dunn for check the final version of the manuscript in English. This study include the Red de Biología y Conservación de Vertebrados and Red de Medio Ambiente y Sustentabilidad of the Instituto de Ecología, A. C. 
Referencias

Anderson, J. D., R. L. Honeycutt, R. A. Gonzalez, K. L. Gee, L. C. Skow, R. L. Gallagher, D. A. Honeycutt, and R. W. DeYoung. 2002. Development of microsatellite DNA markers for the automated genetic characterization of white-tailed deer populations. Journal of Wildlife Management 66:67-74.

Arriaga, L., C. Aguilar, D. Espinosa-Organista, and R. Jiménez. 1997. Regionalización ecológica y biogeográfica de México. Taller de la Comisión Nacional para el Conocimiento y Uso de la Biodiversidad (CONABIO), México, D. F.

BaKer, R. H. 1984. Origin, classification, and distribution. Pages 1-19 in White-tailed deer: ecology and management. (Halls L. K. ed.). Stackpole Books, Harrisburg, Pennsylvania.

Barrowclough, G. F. 1982. Geographic variation, predictiveness and subspecies. Auk 99:601-603.

Briones-Salas, M., and C. García-Cruz. 2005. Estimación de la densidad del venado cola blanca (Odocoileus virginianus oaxacensis) en la sierra norte de Oaxaca. Revista Mexicana de Mastozoología 9:141-145.

Calderón-Lobato, R. D. 2009. Análisis genético para la conservación y manejo de subespecies de Odocoileus virginianus (Zimmermann, 1780) en México. Tesis Maestría, Centro de Biotecnología Genómica, Instituto Politécnico Nacional, México.

Cronin, M. A. 1991 a. Mitochondrial and nuclear genetic relationships of deer (Odocoileus spp.) in western North America. Canadian Journal of Zoology 69:1270-1279.

Cronin, M. A. 1991b. Mitochondrial-DNA phylogeny of deer (Cervidae). Journal of Mammology 72:533-566

Diario Oficial de la Federación. 2006. Ley General de Vida Silvestre. Publicada el 3 de Julio del 2000 y reformada el 26 de Enero del 2006. Cámara de Diputados del H. Congreso de la Unión, Gobierno de los Estados Unidos Mexicanos-SEMARNAT.

Deckman, D. 2003. North American White-tailed deer: distributions and subspecies. Whitetailes Unlimited, Inc. Sturgeon Bay, Wisconsin

Dinerstein, E., D. M. Olson, D. J. Graham, A. L. Webster, S. A. Primm, M. P. Bookbinder, P. Marnie, AND G. Ledec. 1995. Conservation assessment of the terrestrial ecoregions of Latin America and the Caribbean. Banco Mundial, Washington, D.C.

deVos, Jr. J. C., M. R. Conover, and N. E. Headrick (editors). 2003. Mule Deer conservation: issues and management strategies. Berryman Institute Press. Utah State University, Logan, Utah.

DeYoung, R. W., S. Demarais, R. A. Gonzalez, R. L. Honeycutt, and K. L. Gee. 2002. Multiple paternity in white-tailed deer (Odocoileus virginianus) revealed by DNA microsatellites. Journal of Mammalogy 83:884-892.

DeYoung, R. W., S. Demarais, R. L. Honeycutt, A. P. Rooney, R. A. Gonzales, and K. L. GeE. 2003. Genetic consequences of white-tailed deer (Odocoileus virginianus) restoration in Mississippi. Molecular Ecology 12:3237-3252.

Ellsworth, D. L., R. L. Honeycutt, N. J. Silvy, J. W. Bickham, and D. Klimstra. 1994. Historical biogeography and contemporary patterns of mitochondrial DNA variation 
in white-tailed deer from the southeastern United States. Evolution 48:122-136.

ESRI. 1999. Arc View ver. 3.2. Environmental Systems Research Institute, Inc. Redlands, California, USA.

Frankham, R., J. D. Balou, and D.A. Briscoe. 2002. Introduction to conservation genetics. Cambridge University Press, United Kingdom

Galindo-Leal, C., and M. Weber. 2005. Venado Cola Blanca Odocoileus virginianus (Zimmermann, 1780). Pp: 517-521 in Mamíferos Silvestres de México. (Ceballos, G. y G. Oliva eds.). Comisión nacional para el uso y conocimiento de la biodiversidad-Fondo de Cultura Económica, México.

Galindo-Leal, C., and M. Weber. 1994. Translocation of deer subspecies: reproductive implications. Wildlife Society Bulletin 22:117-120.

Galuina, S., and S. Mandujano. 2009. Ecology, management and conservation of ungulate species in Mexico. Tropical Conservation Science 2:116-127. Available online: tropical conservationscience.org.

Gallina, S., S. Mandujano, and C. Delfín-Alfonso. 2007. Importancia de las Áreas Naturales Protegidas para conservar y generar conocimiento biológico de las especies de venados en México. Pp. 187-196 in: Hacia una cultura de conservación de la diversidad, Halffter G, S. Guevara and A. Melic (eds.). Monografías del 3er. Milenio Vol. 6. Sociedad Entomológica Aragonesa, Comisión nacional para el uso y conocimiento de la biodiversidad, Comisnio nacional de áreas naturales protegidas, Instituto de Ecologia A. C. y MAB-UNESCO.

Gallina, S., S. Mandujano, J. Bello, H. López-Arevalo, and M. Weber. 2010. White-tailed deer Odocoileus virginianus (Zimmermann, 1780). Pp. 101-118 in Neotropical Cervidology (Barbanti, J.M., and González. S. eds.). Funep/IUCN, Jaboticabal.

González-Marín, R. M., E. Montes, and J. Santos. 2003. Caracterización de las unidades de manejo para la conservación, manejo y aprovechamiento sustentable de la fauna silvestre en Yucatán, México. Tropical and Subtropical Agroecosystems 2:13-21.

González-Pérez, G., ANd M. Briones-Salas. 2000. Venado cola blanca (Odocoileus virginianus) en comunidades indígenas de Oaxaca. Investigación Hoy 94:20-27.

GreenberG, L. S. Z. 1992. Garden hunting among the yucatecan maya: a coevolutionary history of wildlife and culture. Etnoecologica 1:23-33.

Hall, E. R. 1981. The mammals of North America. John Wiley and Sons, New York, New York.

Hall, E. R. and K. R. Kelson. 1959. The mammals of North America. Ronald Press Co., New York.

Hammer, Ø., D. A. T. Harper, D.A.T., and P. D. Ryan. 2001. PAST: Paleontological Statistics Software Packagesoftware package for Education and Data Analysis. Palaeontologiaeducation and data analysis. Paleontological Electronica 4:9.http:// palaeo-electronica.org/2001_1/past/issue1_htm

Heffelfinger, J. 2006. Deer of the Southwest: a complete guide to the natural history, biology, and management of southwestern mule deer and white-tailed deer. Texas A \& M University Press, College Station, Texas.

Heffelfinger, J. R., C. Brewer, C. H. Alcalá-Galván, B. Hale, D. L. Weybright, B. F. Wakeling, L. H. Carpenter, AND N. L. Dodd. 2006. Habitat Guidelines for Mule Deer: Southwest 
Deserts Ecoregion. Mule Deer Working Group, Western Association of Fish and Wildlife Agencies.

Heffelfinger, J. R., L. H. Carpenter, L. C. Bender, G. L. Erickson, M. D. Kirchioff, E. R. Loft, AND W. M. Glasgow. 2003. Ecoregional differences in population dynamics. Pages 63-91 in Mule Deer Conservation: Issues and Management Strategies. (deVos, J. C., M. R. Conover, N. E. Headrick, edis.). Western Association of Fish and Wildlife Agencies and Jack $\mathrm{H}$. Berryman Institute, Logan, Utah.

Kellog, R. 1956. What and where are the whitetails? Pp. 31-55 in The deer of North America. (Taylor W. P. ed.). The Stackpole Company, Harrisburg, Pennsylvania.

Kock, R. A., P. S. Soorae, And O. B. Mohammed. 2007. Role of veterinarians in reintroductions. International Zoo 41:24-37.

Krausman, P. R., D. J. Schmidiy, and E. D. Ables. 1978. Comments on the taxonomic status, distribution, and habitat of the Carmen Mountains white-tailed deer (Odocoileus virginianus carminis) in Trans-Pecos Texas. The Southwestern Naturalist 23:577590.

Leopold, A. S. 1959. Wildlife of Mexico. University of California Press, Berkeley, California Logan-López, K, E. Cienfuegos-Rivas, F. C. Sánchez, G. Mendoza, A. M. Sifuentes, and L. A. TARANFo. 2006. Caracterización morfométrica de cuatro subespecies de venado cola blanca (Odocoileus virginianus) en la zona noreste de México. Revista Científica 1:14-22.

logan-López, K, E. Cienfuegos-Rivas, A. M. Sifuentes, M. González, F. Clemente-Sánchez, G. Mendoza, and L. A. Taranfo. 2007. Patrones de variación genética en cuatro subespecies de venado cola blanca del noreste de México. Agrociencia 41:13-21.

Mandujano, S. 2004. Análisis bibliográfico de los estudios de venado en México. Acta Zoologica Mexicana (nueva serie) 20:211-251.

Mandujano, S., and V. Rico-Gray. 1991. Hunting, use, and knowledge of the biology of the white-tailed deer, Odocoileus virginianus (Hays), by the Maya of central Yucatan, Mexico. Journal of Ethnobiology 11:175-183.

Mathews, N. E., and W. F. Porter. 1993. Effect of social structure on genetic structure of free-ranging white-tailed deer in the Adirondack mountains. Journal of Mammology 74:33-43.

MaYr, E. 1982. Of what use are subspecies? Auk 99:593-595.

Mayr, E., AND P. D. Ashrock. 1991. Principles of systematic biology. McGraw-Hill, New York, New York

Miller, F. S., ANd R. Kellogg. 1955. List of North American recent mammals. U. S. National Museum, Bulletin 1-954.

Montiel-Ortega, S., L. M. Arias, and F. Dickinson. 1999. La cacería tradicional en el norte de Yucatán: una práctica comunitaria. Revista Geografía Agrícola 29:43-51.

Moodley, Y., AND M. W. Bruford. 2007. Molecular biogeography: towards an integrated framework for conservation Pan-African biodiversity. PLoS ONE 5:e454

Morrone, J. J. 2005. Hacia una síntesis biogeográfica de México. Revista Mexicana de Biodiversidad 76:207-252.

Naranjo, E. J., Guerra M. M., Bodmer R. E, and Bolaños J. E. 2004. Subsistence hunting by three ethnic groups of the Lacandon forest, México. Journal of Ethnobiology 24:233-253. 
Olson, D. M., E. Dinerstein, E. D. Wikramanayake, N. D. Burgess, G. V. N. Powell, E. C. Underwood, J. A. D'amico, I. Itoua, H. E. Strand, J. C. Morrison, C. J. Loucks, T. F. Allnutt, T. H. Ricketts, Y. Kura, J. F. Lamoreux, W. W. Wettengel, P. Hedao, and K. R. KASSEM. 2001. Terrestrial Ecoregions of the World: A New Map of Life on Earth a new global map of terrestrial ecoregions provides an innovative tool for conserving biodiversity. BioScience 51:933-938.

Ortiz-Martínez, T., S. Gallina, M. Briones-Salas, and G. González-Pérez. 2005. Densidad poblacional y caracterización del hábitat del venado cola blanca (Odocoileus virginianus oaxacensis, Goldman y Kellogg, 1940) en un bosque templado de la sierra norte de Oaxaca, México. Acta Zoológica Mexicana (n. s.) 21:65-78.

Palacio, J. L., G. Bocco, A. Velásquez, J. F. Mas, F. Takaki, A. Victoria, L. Luna, G. Gómez, J. López, M. Palma, I. Trejo, A. Peralta, J. Prado, A. Rodríguez, R. Mayorga, and F. González. 2000. La condición actual de los recursos forestales en México: resultados del Inventario Forestal Nacional. 2000. Investigaciones Geográficas, UNAM. Boletín Instituto de Geografía 43:183-203.

Philumore, A. B., And I. P. F. Owens. 2006. Are subspecies useful in evolutionary and conservation biology? Proceedings of the Royal Society B 273:1049-1053.

RuE, L., L. 1979. The deer of North America: an illustrated guide to their lives, their world, their relations with man. Book Division, Times Mirror Magazines Inc., Crown Publisher Inc, New York Outdoor Life, USA.

Rzedowski, J., and Reyna-Trujılo, T. 1990. Divisiones florísticas'. Escala 1:8’000,000. En: Tópicos fitogeográficos (provincias, matorral xerófilo y cactáceas. IV.8.3. Atlas Nacional de México. Vol. II. Instituto de Geografía, Universidad Nacional Autónoma México. México.

Segovia, A., and S. Hernández-Betancourt. 2003. La cacería de subsistencia en Tzucacab, Yucatán, México. Tropical and Subtropical Agroecosystems 2:49.

Sheffield,S. R., R. P. Morgan II, G. A. Feldhamer, and D. M. Harman. 1985. Genetic variation in white-tailed deer (Odocoileus virginianus) populations in western Maryland. Journal of Mammalogy 66:243-255.

Sмiтh, W. P. 1991. Odocoileus virginianus. Mammalian Species 388:1-13.

Storfer, A. 1999. Gene flow and endangered species translocations: a topic revisited. Biological Conservation 87:173-180.

Taylor, W. P. 1956. The Deer of North America. Stackpole Company. Harrisburg, PA. 6

Van Den Bussche, R. A., T. G. Ross, and S. R. Hoofer. 2002. Genetic variation at a major histocompatibility locus within and among populations of white-tailed deer (Odocoileus virginianus). Journal of Mammalogy 83:31-39.

Villarreal, J. 1999. Venado Cola Blanca: Manejo y Aprovechamiento Cinegético. Unión Ganadera Regional de Nuevo León. Monterrey, Nuevo León, México.

Villarreal, J. 2009. Propone el CEFFSNL regionalización cinegética de venados cola blanca mexicanos para libro récords internacionales del SCI. Boletín Cuenca Palo Blanco, CEFFNL 4:3-7.

Villarreal-Espino, O. 2002. El grand slam del venado cola blanca mexicano, una alternativa sostenible. Archivos de Zootecnia 51:187-193.

Villarreal-Espino, O. 2006. El Venado Cola Blanca en la Mixteca Poblana: Conceptos y Métodos para su Conservación y Manejo. Fundación Produce Puebla A. C., Puebla. 
A. 2006. El Venado Cola Blanca en la Mixteca Poblana: Conceptos y Métodos para su Conservación y Manejo. Fundación Produce Puebla A. C., Puebla.

Waldrup, K., A. Kocan, R. Barker, and G. Wager. 1990. Transmission of Babesia odocoilei in white-tailed deer by Ixodes scapularis. Journal of Wildlife Diseases 26:390-391.

Worldwide Fund for Nature. 1999. WWF in action. Ecoregion-based conservation. [WWF's Global Conservation Programme 1999/2000]. Available from: http://www. panda.org/resources/publications/sustainability/global/eco-based.html (accessed June 19, 2002).

Sometido: 3 octubre 2009

Revisado: 14 enero 2010

Aceptado: 18 febrero 2010

Editor asociado Jan Schipper 



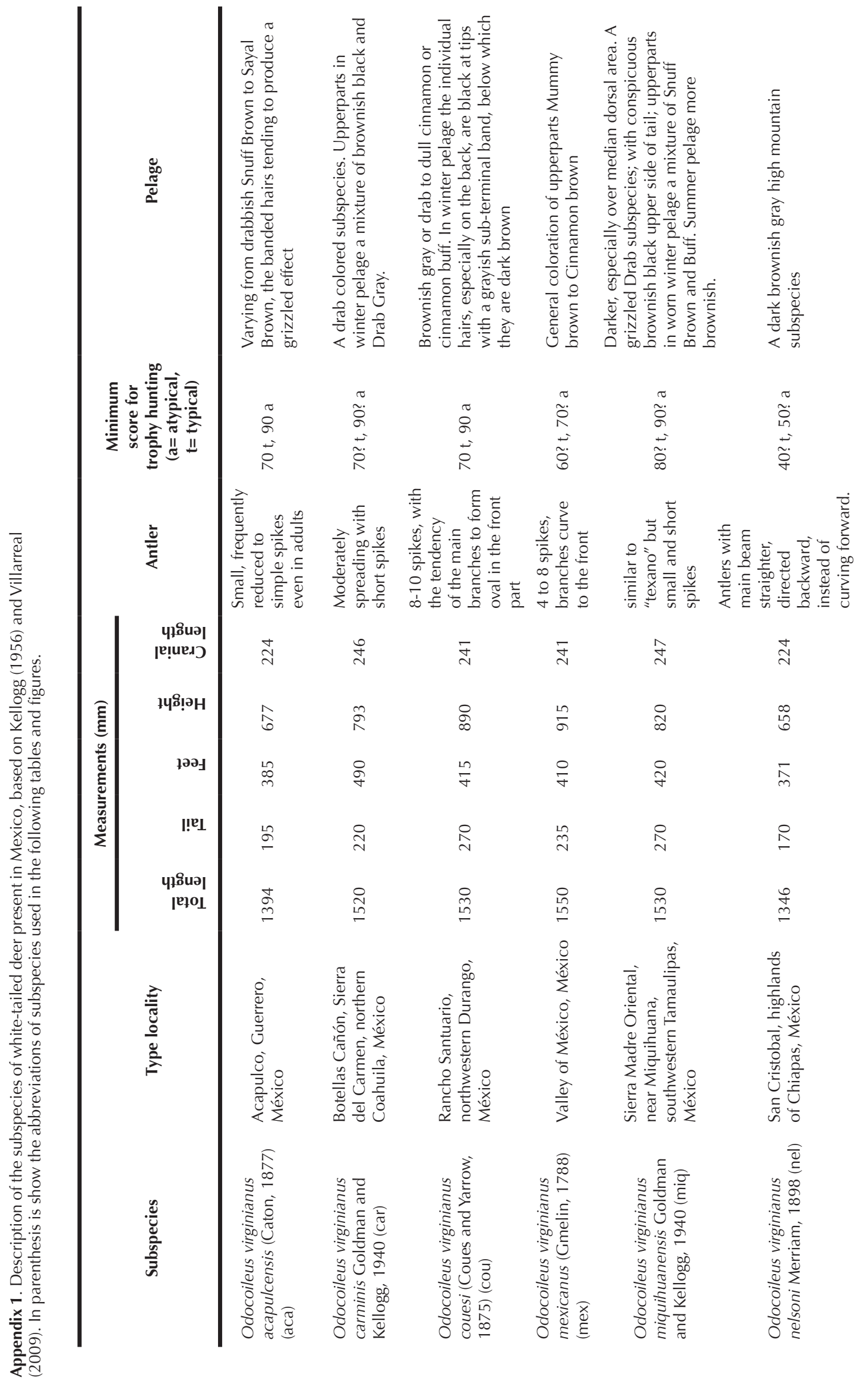



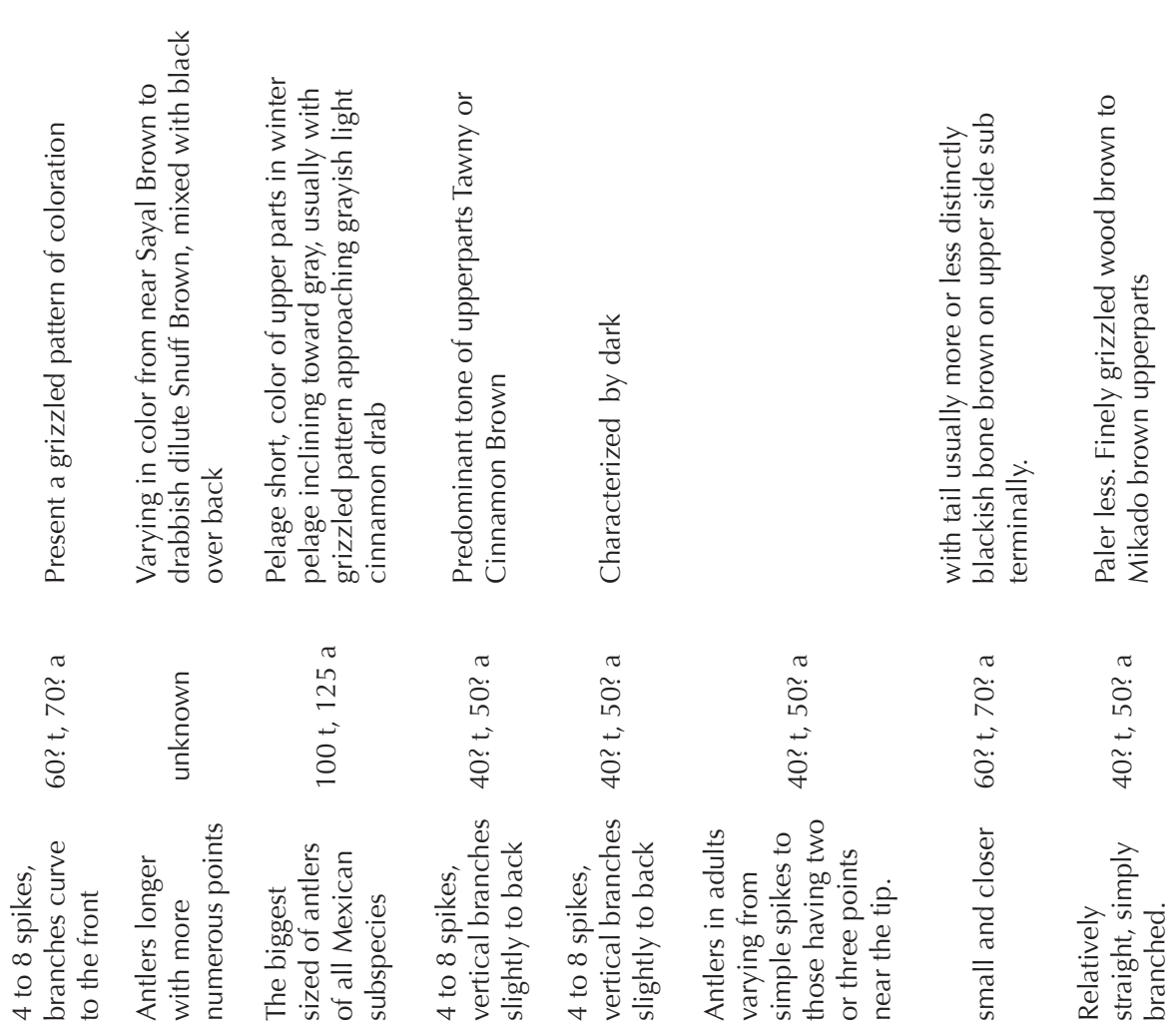

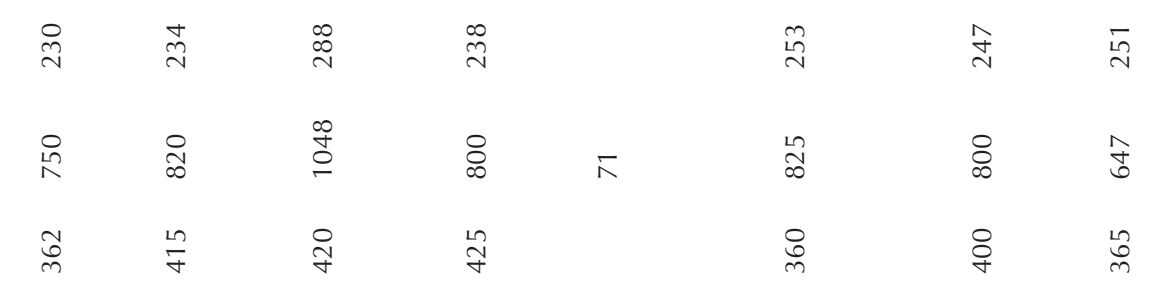

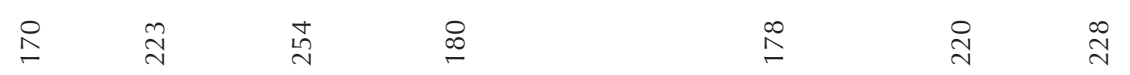

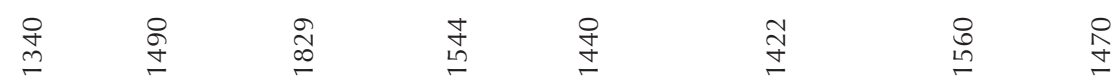
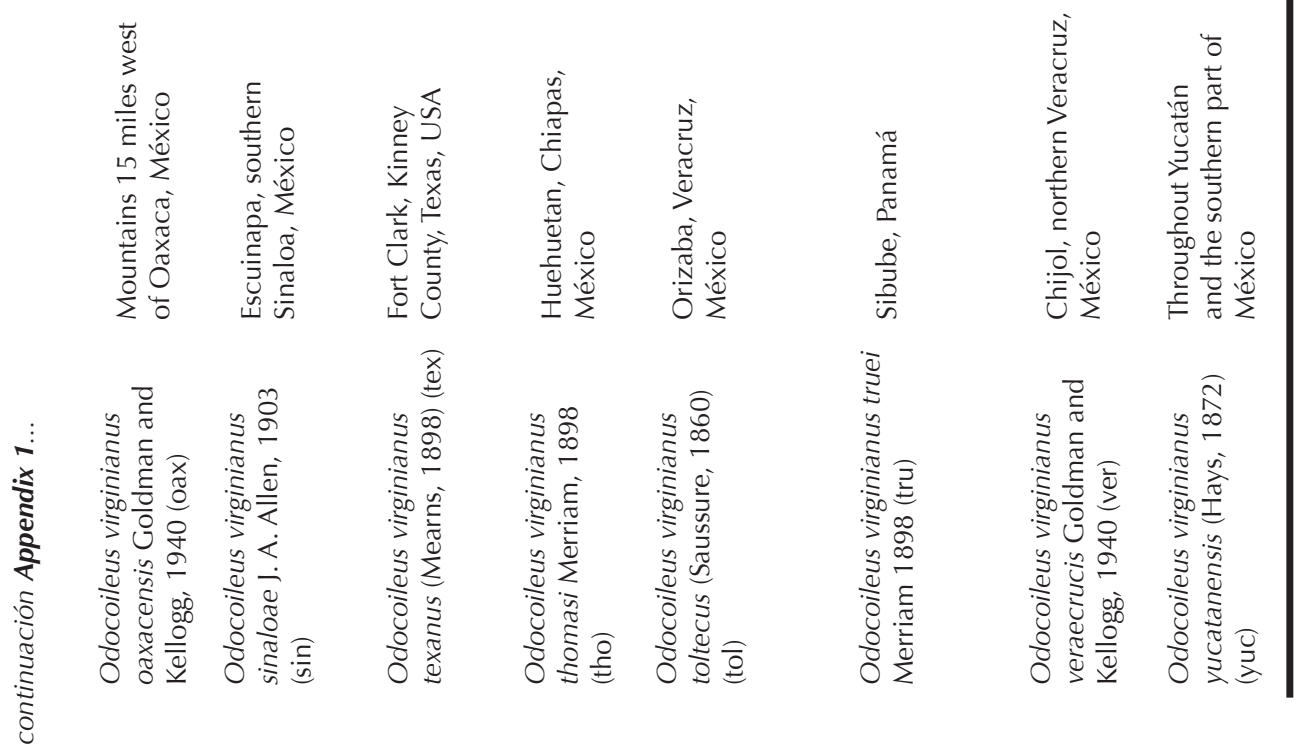
